УДК 556.3

\title{
КОМПЛЕКСНАЯ ОЦЕНКА ГИДРОГЕОЛОГИЧЕСКИХ УСЛОВИЙ ФОРМИРОВАНИЯ РЕСУРСОВ МИНЕРАЛЬНЫХ ВОД НИЖНЕ-КАРМАДОНСКОГО МЕСТОРОЖДЕНИЯ
}

\author{
Клюев Роман Владимирович1, \\ kluev-roman@ramler.ru
}

\section{Голик Владимир Иванович²,} v.i.golik@mail.ru

\author{
Босиков Игорь Иванович², \\ igor.boss.777@mal.ru \\ 1 Московский политехнический университет, \\ Россия, 107023, г. Москва, ул. Б. Семеновская, 38. \\ 2 Северо-Кавказский горно-металлургический институт (государственного технологического университета), \\ Россия, 362021, г. Владикавказ, ул. Николаева, 44.
}

\begin{abstract}
Актуальность. На протяжении многих веков человечество использует источники иелебных вод. Минеральная вода применяется как для лечения, так и для целей профилактики. При этом ее целебные свойства проявлялись при повсеместном использовании. Уже начиная с XV в. до нашей эры индийские Веды дают представления об уникальных свойствах минеральных вод. Воду из минеральных и пресных источников использовали для целей гигиены и лечения в Древнем мире, в частности в Египте, Вавилоне, Ассирии. Следует отметить, что всегда давалась высокая оценка именно подземным водам. Исследования обусловлены необходимостью комплексного исследования Нижне-Кармадонского месторождения для пополнения запасов минеральных вод в Российской Федерации.

Цель: проведение комплексного анализа химического состава минеральных вод Нижне-Кармадонского месторождения и определение физико-химических и лечебных свойств минеральных вод месторождения.

объекты: минеральные воды Геналдонского ущелья, Нижне-Кармадонского месторождения, Казбекско-Джимарайского массива.

Методы: структурно-тектонический метод, метод аналогий, метод моделирования, геофизические методы - термокаротажные исследования скважин, метод фациального анализа, геоморфологический метод, метод геометризации недр. Геотермические условия участка недр оценивались путем замеров температуры воды на устьях скважин.

Результаты. По проведенным исследованиям, согласно ГОСТ Р 54316-2011 и «Основным критериям химического состава минеральных вод», воды месторождения являются мало- и среднеминерализованными, хлоридными натриевыми, борными, высокотермальными. По физико-химическим и лечебным свойствам минеральные воды участка недр ООО «Ариана» рекомендованы в лечебно-питьевых целях согласно прилагаемым медицинским показаниям. Исходя из величины постоянной разгрузки

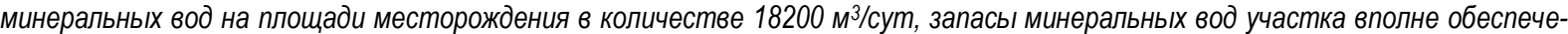
ны источниками формирования.
\end{abstract}

\section{Ключевые слова:}

Термальные минеральные и хлоридные натриевые воды, зоны разломов и трещиноватости, месторождение, комплекс трещинно-жильных вод, термокаротажнье исследования скважин, зоны разломов, трещины.

\section{Введение}

Рассматриваемый в работе участок является южной частью Нижне-Кармадонского месторождения термальных минеральных вод и находится в 35 км к ЮЮЗ от г. Владикавказа, в горной части Республики Северная Осетия-Алания (Геналдонское ущелье), на левом берегу р. Геналдон (рис. 1).

Участок является южной частью НижнеКармадонского месторождения минеральных вод, расположен в пределах Казбекско-Джимарайского горно-ледникового массива Бокового Кавказского хребта (рис. 2). Минеральные воды приурочены к зонам разломов и повышенной трещиноватости в толще осадочных пород $\mathrm{J}_{1}$. В структурном отношении участок приурочен к сводовой части Геналдонской антиклинали, входящей в состав тектонической зоны Ceверного склона антиклинория Большого Кавказа. Нижне-Кармадонское месторождение разведано в конце XX в. 12-ю скважинами; запасы в количестве 2200 м 3 сут утверждены протоколом ГКЗ СССР по категории А. В соответствии с кондициями воды месторождения термальные $\left(33-55{ }^{\circ} \mathrm{C}\right)$, метановоазотные, хлоридные (реже гидрокарбонатнохлоридные) натриевые, борные, средней минерализации $\left(2,8 \ldots 5,8\right.$ г/дм $\left.{ }^{3}\right)$.

Все разведочные скважины к настоящему времени ликвидированы. В процессе гидрогеологических исследований в 2014-2015 гг. бурение новых скважин не осуществлялось; переоценка запасов произведена по двум эксплуатационным скважинам № 27 и 29-р, проявившимся после катастрофического схода ледника Колка 20.09.2002 г. [1-13]. Воды жильно-трещинные, вскрыты на глубине 330-817 м. Минеральные воды скважины самоизливаются с избыточным напором до +400 м (расчетная величина). В процессе работ оценен режим скважин № 27 и 29-р, качественный состав воды, санитарно-экологическое состояние участка и при- 
легающей территории; по фондовым материалам охарактеризован целевой водоносный комплекс $\mathrm{J}_{1}$. За период с 1957 г. по настоящее время качественный состав минеральных вод стабильный. По данным современных исследований воды термальные $\left(43-50{ }^{\circ} \mathrm{C}\right)$ хлоридные (гидрокарбонатно-хлоридные), натриевые, борные, Кармадонского и Урсдонского типов, лечебные, с минерализацией 3,2 ...5,7 г/дм ${ }^{3}$. Подсчитаны запасы гидравлическим методом $[1,2]$ по категории В (разведанные) - $152 \mathrm{~m}^{3} /$ сут.

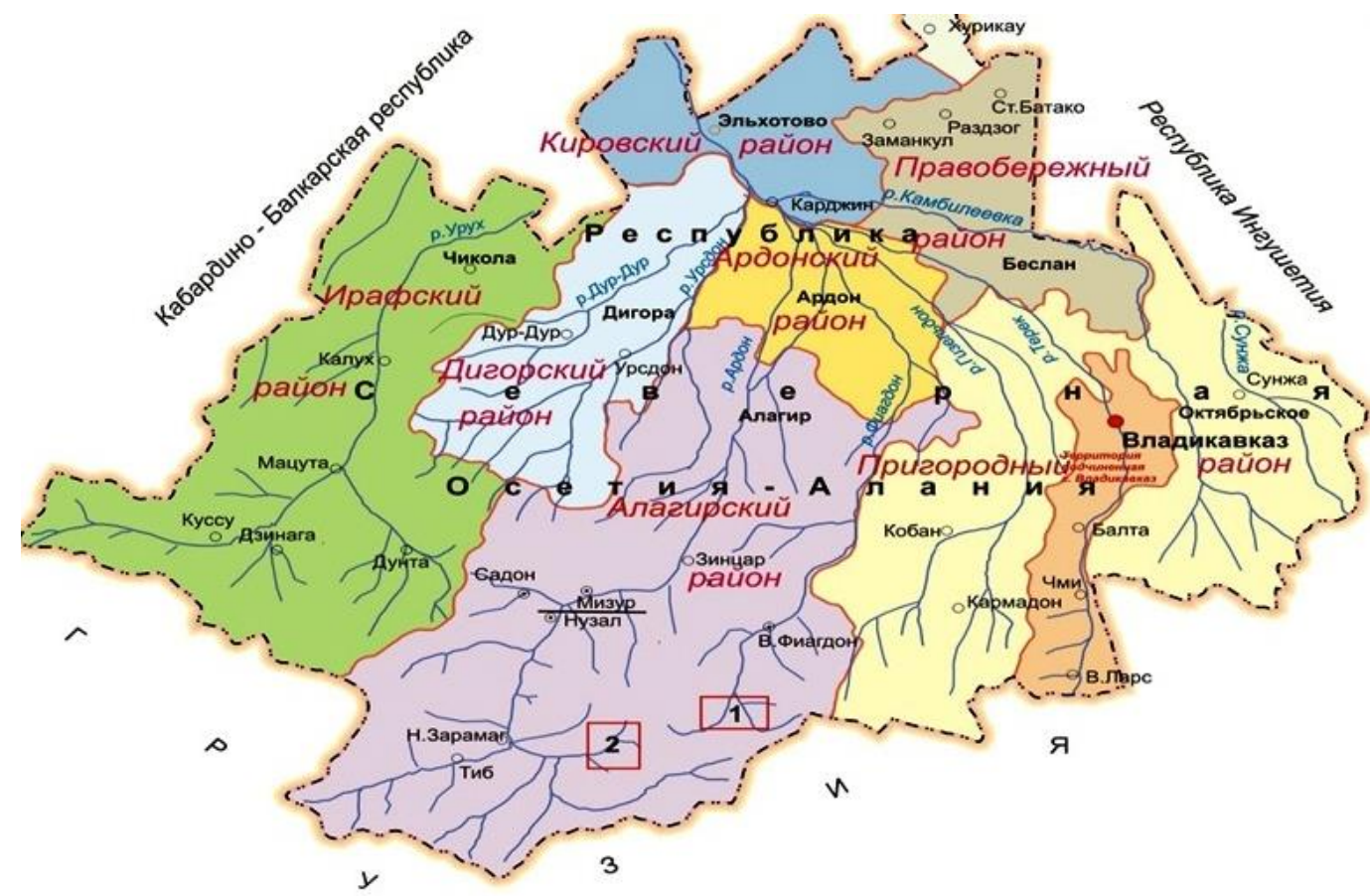

Условные обозначения:

\begin{tabular}{|c|c|}
\hline 1 & - Нижне-Камадонское месторождение \\
\hline \hline 2 & - Верхне-Камадонское месторождение
\end{tabular}

Pис. 1. Обзорная карта РСО-Алания. Масштаб 1:750000

Fig. 1. Overview map of North Ossetia-Alania. Scale 1:750000

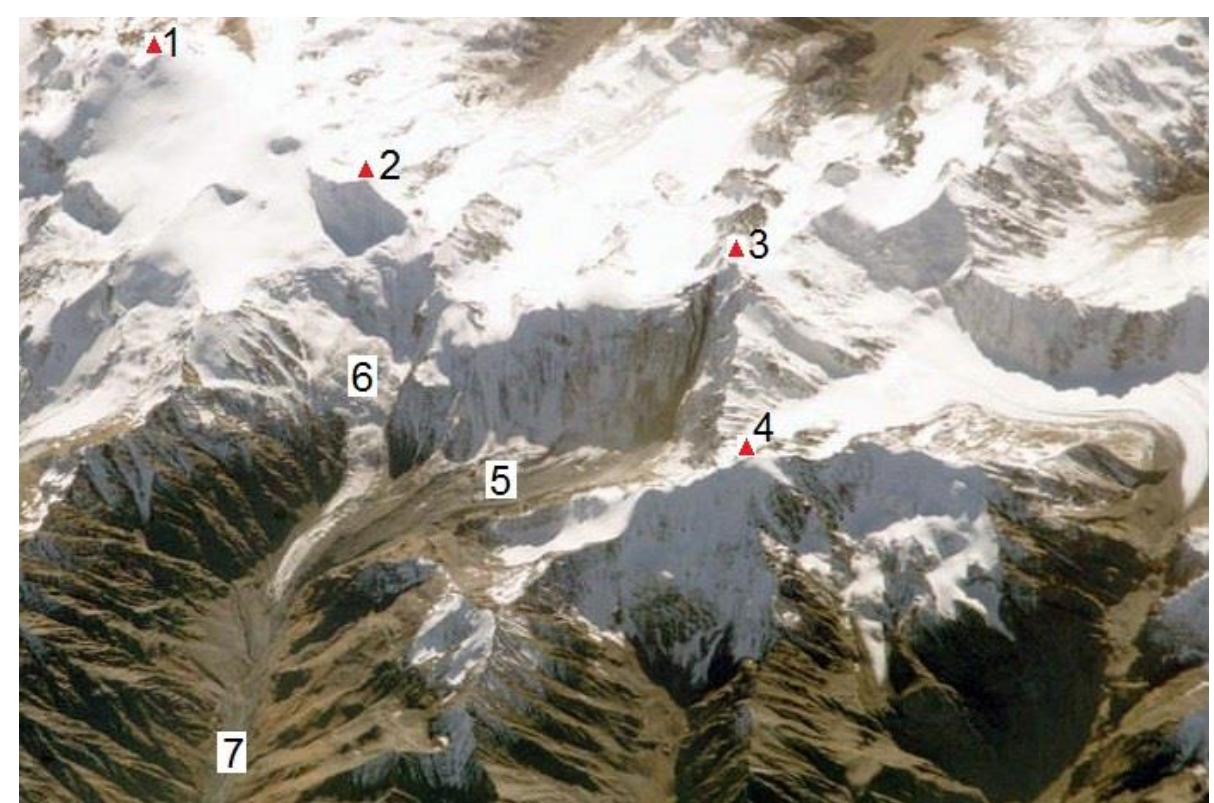

Pис. 2. Казбекско-Джимарайский массив (вид с северо-востока): 1 - гора Казбек; 2 - гора Майлихох; 3 - гора Джимарайхох; 4 -гора Шаухох; 5 -ложе ледника Колка; 6-ледник Майли; 7 - долина р. Геналдон (исток)

Fig. 2. Kazbek-Dzhimarai massif (view from the north-east): 1 - Mount Kazbek; 2 - Mount Mailikhokh; 3 - Mount Dzhimaraikhokh; 4 -Mount Shaukhokh; 5 - the Kolka glacier bed; 6-Mayli glacier; 7 - valley of the Genaldon river (source) 


\section{Структурно-тектоническое}

\section{и гидрогеологическое положение}

Участок недр ООО «Ариана», являющийся южной частью Нижне-Кармадонского месторождения минеральных вод [1,2], в геоструктурном отношении приурочен к тектонической зоне Северного склона (структура II порядка), входящей в состав антиклинория Большого Кавказа (структура I порядка). Зона Северного склона - сложное складчато-глыбовое сооружение, в основе которого лежит крупная продольная структура, представленная серией кулисообразно залегающих антиклинальных складок, ограниченных поперечными поднятиями и прогибами.

Основным тектоническим элементом зоны Северного склона, обуславливающим геологическое строение оцениваемого участка недр, является Геналдонская антиклиналь (структура III порядка), возникшая в результате глыбового движения кристаллического фундамента. Антиклиналь расположена в средней части долины р. Геналдон.

Геналдонская антиклиналь сложена нижнеюрскими отложениями, сильно сжата и опрокинута на север, вследствие чего ее осевая плоскость круто $\left(80-85^{\circ}\right)$ наклонена к югу, а породы в крыльях залегают изоклинально с падением к югу и юго-востоку.

К востоку и западу от долины р. Геналдон (рис. 3) шарнирная часть Геналдонской антиклинали испытывает погружение, вследствие чего антиклиналь имеет характер брахиантиклинали. Кроме того, верхняя часть антиклинали размыта, в результате чего породы фундамента залегают на меньшей глубине, чем на прилегающих к месторождению площадях, где фундамент располагается, по-видимому, на глубине не менее $2000 \mathrm{M}$.

В пределах Геналдонской антиклинали установлены разрывные нарушения, среди которых наиболее крупными являются Кауридонский, НижнеКармадонский сброс и Тагаурский взброс амплитудами около 1500 м. Все эти нарушения имеют общее субширотное простирание и крутое $\left(80-90^{\circ}\right)$ падение на юг. Таким образом, эти сбросы и взбросы секут Геналдонскую антиклиналь под острым углом к ее простиранию.

Наряду с крупными разрывными дислокациями антиклиналь разбита многочисленными мелкими нарушениями типа сбросов и зон дробления, среди которых преобладают нарушения северо-западного $\left(310-320^{\circ}\right)$ простирания с крутыми $\left(80-90^{\circ}\right)$ падениями на юго-запад.

Также здесь имеются поперечные разломы субмеридионального простирания, слабо изученные по той причине, что направление их совпадает с направлением долины р. Геналдон.

В пределах Геналдонской антиклинали породы сильно трещиноваты. Среди трещин наиболее распространенными являются трещины субмеридионального (ССВ) простирания с крутым падением к востоку и западу. Ввиду того, что простирание данных трещин совпадает с направлением долины р. Геналдон, изучены они слабо.

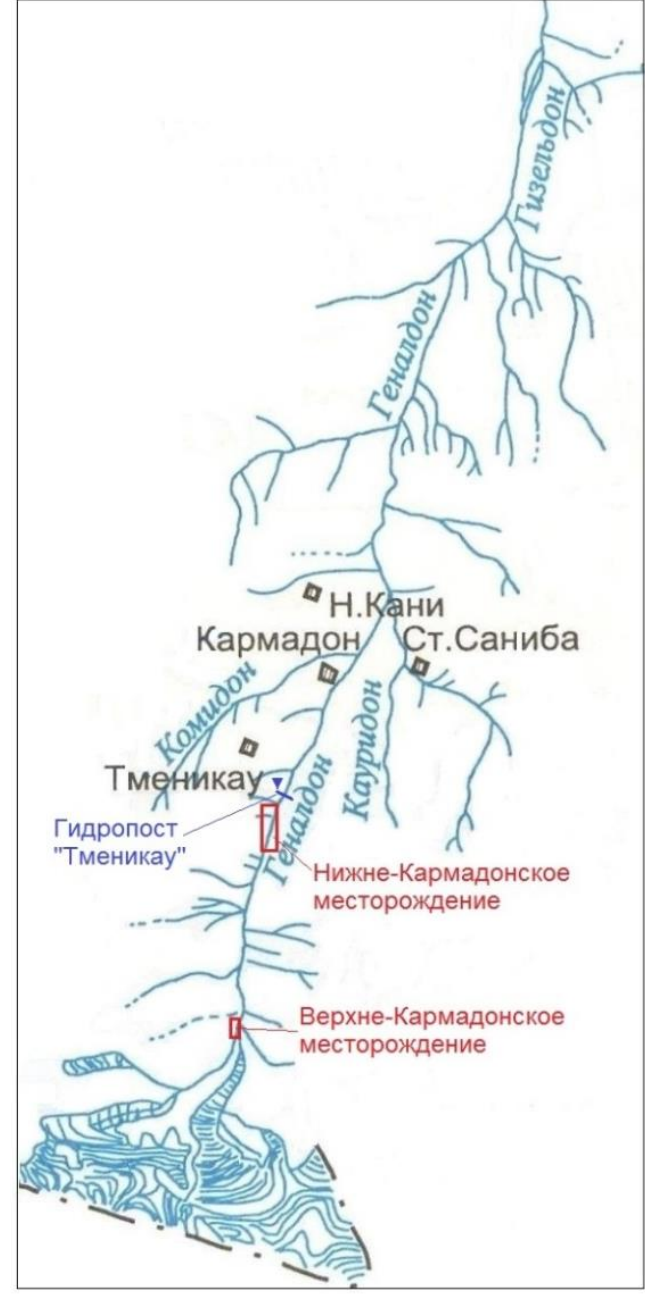

Pис. 3. Бассейн реки Геналдон

Fig. 3. Genaldon river basin

Меньшим распространением пользуются здесь трещины северо-западного и субширотного простирания с падением на юго-запад под углами $50-75^{\circ}$. Последние обычно сгруппированы в зоны трещиноватости значительной протяженности. По типу они являются трещинами скола.

Предыдущими исследователями установлено, что трещины скола притерты и закрыты или выполнены глинистым веществом, в то время как субмеридионально-поперечные трещины разрыва чаще открыты, в связи с чем являются основным путями циркуляции минеральных вод [3-5].

Таким образом, геологическая обстановка НижнеКармадонского месторождения сложная, для нее характерна сильная раздробленность и трещиноватость пород.

Ввиду того, что оцениваемый участок недр ООО «Ариана» входит в состав Нижне-Кармадонского месторождения, он рассматривается как южная часть мощного очага разгрузки термальных минеральных вод, приуроченного к Геналдонской антиклинальной структуре. Последняя разбита крупными Кауридонским, Нижне-Кармадонским и Тагаурским субширотными разломами с амплитудами до 1500 м, а также сопряженными с ними многочисленными мелкими разрывными нарушениями и зонами трещиноватости. 
Крупные тектонические разломы субширотного простирания, будучи трещинами скола, отличаются значительной притёртостью и представляют собой серию зеркал скольжения с глинкой трения, зоны смятия, интенсивного дробления и брекчирования пород мощностью до 20 м. Оперяющие трещины северо-западного и северо-восточного простирания характеризуются незначительной протяжённостью, часто залечены кварц-кальцитовым материалом или закальматированы. Следовательно, как крупные, так и оперяющие разломы субширотного простирания не могут служить путями циркуляции подземных вод на месторождении. Циркуляция минеральных вод и их разгрузка происходят, по-видимому, по разломам и трещинам субмеридианального направления. При этом участки наибольшей приподнятости кристаллического основания (в ядре Геналдонской антиклинали), где трещины более приоткрыты, являются максимально благоприятными в смысле выведения минеральных вод на поверхность.

Водовмещающими породами на участке являются нижнеюрские терригенные отложения мизурской $\left(\mathrm{J}_{1} \mathrm{mz}\right)$ и кистинской $\left(\mathrm{J}_{1} \mathrm{kst}\right)$ свит. Таким образом, в качестве целевого гидростратиграфического таксона для оцениваемого участка недр ООО «Ариана» можно рассматривать водоносный комплекс трещинножильных вод нижнеюрских отложений (рис. 4).

Питание водоносного комплекса происходит на ледниках и снежниках Казбекско-Джимарайского массива, а также на склонах долины р. Геналдон за счет атмосферных осадков.

Как показало бурение скважин в прошлые годы, верхняя часть пород мизурской свиты (до глубины 50-80 м) обводнена за счет их трещиноватости в зоне выветривания (трещинно-грунтовые воды). Ниже зоны выветривания количество трещин быстро уменьшается и породы становятся менее водообильными. Здесь водоносность пород носит локальный характер, воды циркулируют главным образом в зонах разломов и повышенной трещиноватости (трещинножильные воды). С глубиной минерализация воды увеличивается, так, например, в процессе бурения скв. № 27 в интервале 602-760 м отмечался приток вод с минерализацией порядка $3 \Gamma^{2}$ дм $^{3}$, а в интервале 780-1225 м - с минерализацией более 6 г/дм ${ }^{3}$.

На ранней стадии изучения Нижне-Кармадонского месторождения были определены основные параметры, характеризующие гидрогеологические свойства вскрытых разведочными скважинами водоносных зон. Значения водопроводимости, рассчитанные по данным восстановления уровней в целом для всего месторождения, варьируют от 0,447 до $11,86 \mathrm{~m}^{2} / \mathrm{c}$, коэффициент пьезопроводности (а) - от $0,77 \cdot 10^{4}$ до $3,78 \cdot 10^{5} \mathrm{~m}^{2} / \mathrm{c}$. Значение последнего конкретно для оцениваемого участка недр, по-видимому, меньше, так как по данным разведочной скв. № 6 (южная часть участка недр ООО «Ариана») составило $0,055 \cdot 10^{4} \mathrm{M}^{2} /$ сут.

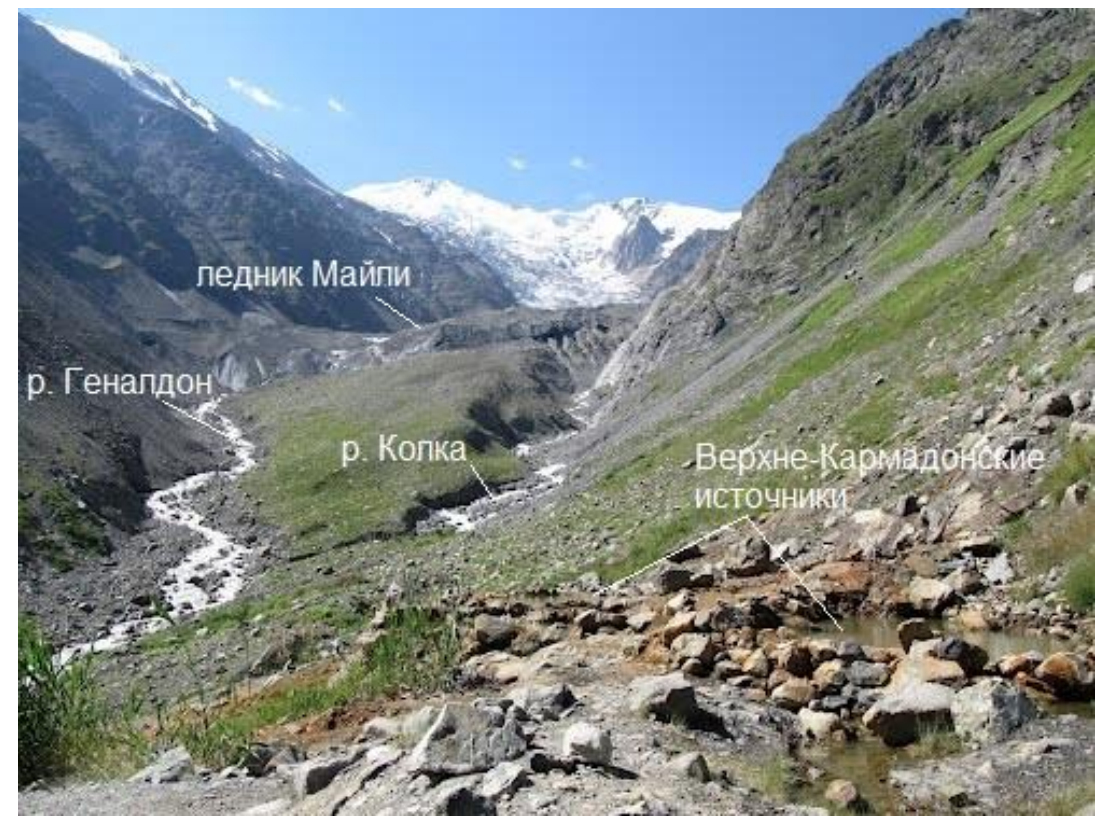

Pис. 4. Верхне-Кармадонские источники

Fig. 4. Upper Karmadon sources

При исследовании месторождения большая часть скважин взаимодействовала между собой. Значения коэффициентов влияния колеблются от 0,67 до 0,75 . Коэффициенты снижения дебита по взаимодействующим скважинам варьировали от 0,15 до 0,25.

По данным современных режимных наблюдений минеральные воды участка обладают высокими напо- рами от +285 м (замеренное в скв. № 27) до +400 м (расчетное для скв. № 29-р). Наличие значительных напоров обуславливает разгрузку минеральных вод в источниках (преимущественно малодебитных). Циркулирующие по разломам и трещинам воды выходят под делювиально-аллювиальный комплекс осадков, поэтому на месторождении распространены в основ- 
ном минеральные источники рассредоточенного типа. Наличие довольно мощного (иногда до 65 м) четвертичного покрова затрудняет фильтрацию трещинножильных вод к поверхности (они, по-видимому, растекаются по этим отложениям), и поэтому на оцениваемом участке отмечается всего два более или менее чётко выраженных источника вод. Этот же фактор определяет и значительное разубоживание минеральных вод источников водами из трещин и грунтов, текущих со стороны коренных склонов [6-10].

Значительное количество подземных вод разгружается в аллювий или непосредственно в р. Геналдон. Последнее обстоятельство обуславливает довольно высокую минерализацию воды в реке в створе Нижне-Кармадонского месторождения (до $0,47 \mathrm{r}^{2} \mathrm{дm}^{3}$ ). Расчёты, произведённые исходя из соотношения минерализации воды в р. Геналдон и выносимых в реку минеральных и пресных вод из скважин (на примере скв. № 29-р), показали, что суммарная величина невидимой разгрузки может достигать более 200 дм³ $^{3}$.

Геотермические условия участка недр оценивались путем замеров температуры воды на устьях скв. № 27, 29-р и 30. Наблюдениями установлено, что на протяжении всего календарного года температура воды на устьях скважин остается стабильной, составляя в среднем для скважин № 29-р и 27, соответственно, 43 и $50{ }^{\circ} \mathrm{C}$. Высокие температуры минеральных вод и их стабильность указывают на то, что они поднимаются с больших глубин (порядка 1500-2000 м от поверхности рельефа), по-видимому, из домезозойского фундамента, который в пределах месторождения залегает примерно на той же глубине.

Более детальными термокаротажными исследованиями прошлых лет в скв. № 27 была установлена геотермическая ступень (расстояние по глубине, на котором температура повышается на $1{ }^{\circ} \mathrm{C}$ ), составившая 13,7 м. Полученная величина геотермической ступени значительно меньше таковых для условий Северного Кавказа в целом, тем не менее она отражает общую закономерность геотермических условий оцениваемого участка недр [11-15]. По характеру размещения изотерм на участке наблюдается геотермическая аномалия, обуславливающая повышенную температуру минеральных вод. Наличие такой аномалии объясняется залеганием на глубине около 2000 м (ниже уровня моря) магматической камеры с температурой $270-300{ }^{\circ} \mathrm{C}$.

\section{Образование газового и химического состава минеральных вод}

Вопрос формирования минеральных вод НижнеКармадонского месторождения, безусловно, сложный. На этапе детальной разведки месторождения в середине XX в. гидрогеологами была предпринята попытка решить данный вопрос на основании полученного фактического материала и общих представлений о геолого-гидрогеологической обстановке района. При этом авторы статьи признали, что данный фактический материал является довольно ограниченным и крайне недостаточным для окончательного суждения об условиях формирования Нижне-Кармадонских минеральных вод.

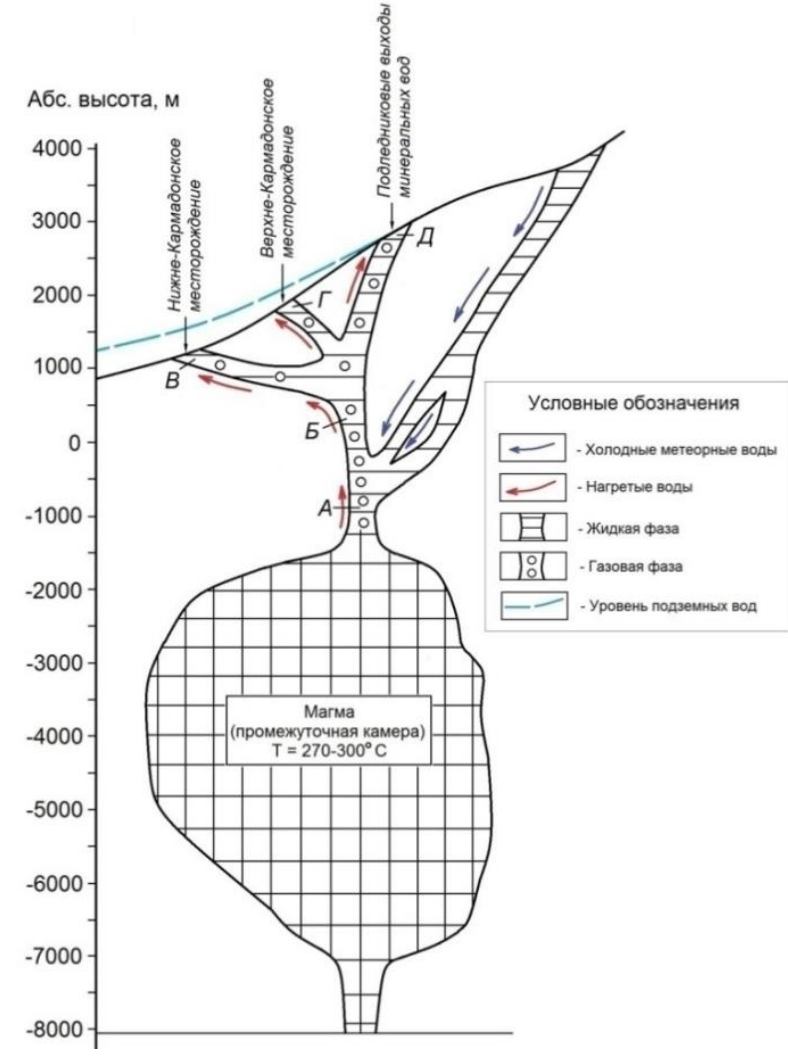

Pис. 5. Схема возможного преобразования магматогенных газово-жидких растворов: $A$ - гидротермальный Cl-Na раствор: нагретые воды, пар и газы $\left(\mathrm{O}_{2}, \mathrm{CO}_{2}, \mathrm{H}_{2} \mathrm{~S}, \mathrm{~N}_{2}\right.$ и $\left.\mathrm{CH}_{4}\right) ; \mathrm{B}$ - смеманные $\mathrm{Cl}-\mathrm{Na}$ воды, богатые газами; $B$ - смеманные $\mathrm{HCO}_{3}-\mathrm{Cl}-\mathrm{Na}$ воды $\mathrm{c}$ газами (НижнеКармадонское месторождение); $\Gamma$-смеманные $\mathrm{SO}_{4}-\mathrm{HCO}_{3}-\mathrm{Cl}-\mathrm{Na}$ воды $\mathrm{c}$ газами (ВерхнеКармадонское месторождение); Д - $\mathrm{SO}_{4}-\mathrm{Cl}-\mathrm{Na}$ воды с высоким содержанием металлов (подледниковые Колкинские и др. минеральные воды)

Fig. 5. Scheme of possible transformation of magmatogenic gas-liquid solutions: A - hydrothermal $\mathrm{Cl}-\mathrm{Na}$ solution: heated water, steam and gases $\left(\mathrm{O}_{2}, \mathrm{CO}_{2}, \mathrm{H}_{2} \mathrm{~S}\right.$, $\mathrm{N}_{2}$ and $\left.\mathrm{CH}_{4}\right) ; \mathrm{B}-$ mixed $\mathrm{Cl}-\mathrm{Na}$ waters, rich in gases; $\mathrm{B}-$ mixed $\mathrm{HCO}_{3}-\mathrm{Cl}-\mathrm{Na}$ water with gases (NizhneKarmadon field); $\mathrm{\Gamma}$ - mixed $\mathrm{SO}_{4}-\mathrm{HCO}_{3}-\mathrm{Cl}-\mathrm{Na}$ waters with gases (Verkhne-Karmadon field); Д $\mathrm{SO}_{4}$ - $\mathrm{Cl}-\mathrm{Na}$ waters with high metal content (subglacial Kolkinskie and other mineral waters)

Учитывая, несомненно, авторитетные мнения гидрогеологов - исполнителей геологоразведочных работ и экспертов ГКЗ РФ, тем не менее, авторы настоящей работы рассматривают универсальную схема формирования химического состава минеральных вод за счет преобразования магматогенных газовожидких растворов (рис. 5). Схема является универсальной и может использоваться для исследований многих месторождений минеральных вод. В своих исследования раннее применяли универсальную схему исследователи: В.М. Максимов, А.В. Щербаков, А.М. Прохоров и др.

По результатам исследований последнее извержение вулкана Казбек произошло около 6000 лет назад. Находясь всего в 4000-4500 м над промежуточной 
магматической камерой вулкана с температурой около 270-300 ${ }^{\circ} \mathrm{C}$ район расположения НижнеКармадонского месторождения однозначно подвержен влиянию поствулканических процессов Казбекского вулканического центра.

Вулканические породы здесь представлены в основном андезитовыми и дацитовыми лавами, т. е. продуктами средней магмы. Для областей современного вулканизма с подобным составом вулканогенов исходным типом выделяющихся гидротерм являются $\mathrm{Cl}-\mathrm{Na}$ растворы, происхождение которых связано с плотными вулканическими парами. Объясняется это тем, что в парах высокой плотности хорошо растворимы хлориды щелочных металлов, кремнезем и рудные минералы. Под влиянием флюидов в конкретной гидрогеологической обстановке образуются нагретые Cl-Na растворы, богатые $\mathrm{Li}, \mathrm{H}_{2} \mathrm{SiO}_{3}$ и $\mathrm{H}_{3} \mathrm{BO}_{3}$.

Исходя из этого можно сделать вывод, что минеральные воды Нижне-Кармадонского месторождения формируются за счет Cl-Na магматогенных растворов в области разгрузки глубинной гидротермальной системы. Структурно такая гидротермальная система является массивным резервуаром, вмещающим трещинно-жильные холодные и термальные воды, гидравлическая связь между которыми обусловлена различными физико-химическими процессами.

Для района расположения Нижне-Кармадонского месторождения представляется следующая концептуальная модель генезиса и распределения подземных вод в гидротермальной системе.

В пределах возвышенных участков КазбекскоДжимарайского горно-ледникового массива холодные метеорные воды по мощным тектоническим разломам проникают на глубину до 500-1000 м ниже нулевой отметки. В качестве таких водопроводящих разломов можно рассматривать субширотный Адайком-Казбекский и поперечный Казбек-Цхинвальский разломы, пересекающиеся в районе горы Казбек (к юго-востоку от района расположения НижнеКармадонского месторождения).

По пути своего движения метеорные воды смешиваются с потоками нагретых вод, пара и газов, восходящими из магматической камеры по зонам проницаемости глубокого заложения. Восходящие потоки, как указано выше, уже изначально состоят из Cl-Na растворов и в значительных количествах содержат $\mathrm{Li}$, $\mathrm{H}_{2} \mathrm{SiO}_{3}, \mathrm{H}_{3} \mathrm{BO}_{3}$, а также газы: $\mathrm{CO}_{2}, \mathrm{O}_{2}, \mathrm{H}_{2} \mathrm{~S}, \mathrm{~N}_{2}$ и $\mathrm{CH}_{4}$.

B результате смешения $\mathrm{Cl}-\mathrm{Na}$ гидротермальных растворов и метеорных вод формируется общий восходящий поток термальных вод, стремящийся в область разгрузки. Следует отметить, что наличие на месторождении восходящего потока как такового (как минимум с глубины 1300 м от поверхности) было однозначно подтверждено ранее проведёнными гидродинамическими и геотермическими исследованиями.

Наиболее благоприятные условия для разгрузки минерализованных вод создаются в местах приподнятых участков кристаллического фундамента в ядрах антиклинальных структур. Для Верхне-Кармадонского месторождения такой структурой является Шаухох- ская антиклиналь, для Нижне-Кармадонского месторождения - Геналдонская антиклиналь. В пределах данных антиклинальных структур установлены зоны разломов и повышенной трещиноватости пород субмеридионального простирания (и, по-видимому, глубокого заложения), наиболее проявленных по долине р. Геналдон (в основном, вдоль русла). Здесь восходящий поток термальных вод разгружается в аллювиальные отложения, в русло реки и на поверхности в виде источников.

Немаловажную роль здесь сыграли эрозионные процессы, сформировавшие в конце последнего оледенения долину р. Геналдон. Возникновение в данном районе глубокой речной долины - естественной дрены - благоприятствовало разгрузке вод глубокой циркуляции, т. е. формированию собственно месторождения термальных хлоридных натриевых вод.

Ввиду того, что движение вод вниз и вверх осуществляется по тектоническим нарушениям (разломам, зонам дробления и повышенной трещиноватости) разнообразного строения и генезиса, а следовательно, и с разной степенью проницаемости, скорости подземных потоков неравномерны. Данное обстоятельство существенным образом сказывается на химическом составе подземных вод месторождения. В частности, воды с повышенной минерализацией, повидимому, обладают более замедленным движением, и, наоборот, для слабоминерализованных вод характерны более активные подземные потоки.

Наличие в составе минеральных вод месторождения гидрокарбонатной составляющей обусловлено дальнейшим смешением хлоридных натриевых вод глубокой циркуляции с пресными трещинногрунтовыми водами преимущественно гидрокарбонатного типа.

\section{Формирование запасов минеральных вод}

Как указано выше, формирование запасов (ресурсов) и химического состава минеральных вод происходит в условиях современного водообмена водоносных структур с поверхностью.

Исходя из общих представлений о формировании хлоридных натриевых вод в исследуемом районе допускается, что минеральные воды месторождений имеют общий генезис $[3,4]$. При этом очевидно, что воды месторождений несколько разичаются между собой по составу и минерализации. Так, воды ВерхнеКармадонских источников относятся к среднеминерализованным и имеют следующий характерный состав:

$$
\mathrm{M}_{8,5} \frac{\mathrm{Cl} 86 \mathrm{HCO}_{3} 12}{(\mathrm{Na}+\mathrm{K}) 78 \mathrm{Ca} 15} .
$$

Воды Нижне-Кармадонского месторождения характеризуются как маломинерализованные, состав их можно описать формулой (скв. № 29-р):

$$
\mathrm{M}_{3,3} \frac{\mathrm{Cl} 85 \mathrm{HCO}_{3} 15}{(\mathrm{Na}+\mathrm{K}) 93} \text {. }
$$

Учитывая пространственное положение месторождений, а именно последовательное их расположение сверху вниз по долине р. Геналдон на расстоянии 
8,5 км друг от друга, допускается влияние вод Верхне-Кармадонского месторождения (с большей минерализацией) на химический состав вод НижнеКармадонского месторождения. В то же время в «окончательном» формировании химического состава вод месторождений участвуют ультрапресные ледниковые воды, пресные воды реки Геналдон, а также трещинно-грунтовые воды юрских отложений. Учитывая эти факторы, в количественном отношении ресурсы подземных вод месторождений можно определить по соотношениям дебитов (расходов) и минерализации поверхностных и подземных вод при их смешении на участках разгрузки.

Верхне-Кармадонское месторождение. Непосредственно на выходе из ледника Майли химический состав воды в р. Геналдон выражается формулой:

$$
\mathrm{M}_{0,7} \frac{\mathrm{Cl} 41 \mathrm{HCO}_{3} 41}{\mathrm{Ca} 47(\mathrm{Na}+\mathrm{K}) 40} \text {. }
$$

Повышенная (в сравнении с общим фоном) минерализация воды в р. Геналдон на выходе из ледника $\left(0,7\right.$ г/дм $\left.{ }^{3}\right)$ свидетельствует о наличии мощного очага разгрузки минерализованных вод под ледником. Кроме того, в зимнее время иногда можно видеть клубы пара, выходящие из трещин ледника. Учитывая минерализацию ледника Майли и значение минерализации Верхне-Кармадонских источников (8,5 $\left.\Gamma / \mathrm{дm}^{3}\right)$ за минерализацию подледникового очага разгрузки, расход подледникового очага разгрузки минеральных вод:

$$
\mathrm{M}_{\Gamma, \mathrm{u}} \cdot \mathrm{Q}_{\Gamma, \mathrm{u}}=\mathrm{M}_{\mathrm{p}} \cdot \mathrm{Q}_{\mathrm{p}, \mathrm{BK}}+\mathrm{M}_{\mathrm{r}} \cdot\left(\mathrm{Q}_{\Gamma, \mathrm{u}}-\mathrm{Q}_{\mathrm{p}, \mathrm{BK}}\right),
$$

где $\mathrm{M}_{\Gamma, и}-$ минерализация воды в истоке р. Геналдон, 0,7 г/дм ${ }^{3} ; \mathrm{Q}_{\Gamma, и}-$ расход воды в истоке р. Геналдон, 800 дм $^{3} / \mathrm{c}$ (или $\left.0,8 \mathrm{~m}^{3} / \mathrm{c}\right) ; \mathrm{M}_{\mathrm{p}}$ - средняя минерализация подледникового очага разгрузки, 8,5 г/дм ${ }^{3} ; \mathrm{Q}_{\mathrm{p}, \mathrm{BK}}-$ расход подледникового очага разгрузки (искомая величина), дм $^{3} / \mathrm{c} ; \mathrm{M}_{л}$ - минерализация ледника Майли (в левой части языка), 0,008 г/дм³ .

Таким образом:

$$
0,7 \cdot 800=8,5 \cdot \mathrm{Q}_{\mathrm{p}, \mathrm{BK}}+0,008 \cdot\left(800-\mathrm{Q}_{\mathrm{p}, \mathrm{BK}}\right),
$$

отсюда расход подледникового очага разгрузки минеральных вод, определяющего ресурсный потенциал Верхне-Кармадонского месторождения, составляет:

$$
Q_{\mathrm{p}, \mathrm{BK}}=65,2 \text { дм }^{3} / \mathrm{c} \approx 5600 \mathrm{~m}^{3} / \mathrm{cyт} .
$$

Нижне-Кармадонское месторождение. Способом аналогичным вышеприведенному рассчитывается примерный расход очага разгрузки подземных вод (прогнозные ресурсы) на участке р. Геналдон в створе Нижне-Кармадонского месторождения. Здесь при смешении вод учитываются пресные трещинногрунтовые воды нижнеюрских отложений и вод p. Геналдон. Формула смешения вод при этом имеет вид:

$$
\mathrm{M}_{\Gamma, \mathrm{HK}} \cdot \mathrm{Q}_{\Gamma, \mathrm{HK}}=\mathrm{M}_{\mathrm{HK}} \cdot \mathrm{Q}_{\mathrm{p}, \mathrm{HK}}+\mathrm{M}_{\mathrm{T \Gamma}} \cdot\left(\mathrm{Q}_{\Gamma, \mathrm{HK}}-\mathrm{Q}_{\mathrm{p}, \mathrm{HK}}\right) \text {, }
$$

где $\mathrm{M}_{\Gamma, н к}-$ минерализация воды в $\mathrm{p}$. Геналдон в ствоpe Нижне-Кармадонского месторождения, 0,47 г/дм³; $\mathrm{Q}_{\Gamma,}-$ расход воды в р. Геналдон в створе месторож-

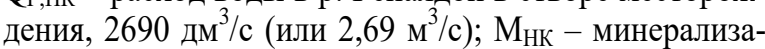
ция воды месторождения (принимается по скв. № 29p), 3,4 г/дм ${ }^{3} ; \mathrm{Q}_{\mathrm{p}, \mathrm{H \kappa}}$ - расход очага разгрузки на площа- ди месторождения (искомая величина), дм $3 / \mathrm{c} ; \mathrm{M}_{\text {тг }}$ средняя минерализация трещинно-пластовых вод, 0,22 г/дм ${ }^{3}$.

Таким образом:

$$
0,47 \cdot 2690=3,4 \cdot \mathrm{Q}_{\mathrm{p}, \mathrm{HK}}+0,22 \cdot\left(2690-\mathrm{Q}_{\mathrm{p}, \mathrm{HK}}\right),
$$

отсюда:

$$
\mathrm{Q}_{\mathrm{p}, \mathrm{HК}}=211,5 \text { дм }^{3} / \mathrm{c} \approx 18200 \mathrm{~m}^{3} / \text { сут. }
$$

Ввиду того, что вышеприведенные расчеты искомой величины подземной разгрузки основаны на данных разновременных наблюдений, они носят, безусловно, приблизительный характер. Для получения более представительной информации о ресурсном потенциале Верхне- и Нижне-Кармадонского месторождений минеральных вод в данном районе требуется организация специальных гидрологических, гидрогеологических и гидрохимических наблюдений.

\section{Группа сложности участка недр}

Район расположения Нижне-Кармадонского месторождения минеральных вод приурочен к восточной окраине Центрально-Кавказской гидрогеологической складчатой области. Данный район характеризуется наличием сложных горно-складчатых сооружений с бассейнами трещинно-грунтовых и трещинно-жильных вод зон тектонических нарушений и контактов.

В соответствии с «Классификацией запасов и прогнозных ресурсов питьевых, технических и минеральных подземных вод», по сложности геологического строения и гидрогеологических условий оцениваемый участок недр можно отнести ко второй группе сложности.

Источники формирования запасов НижнеКармадонского месторождения по данным разведки (1957-1963 гг.) и участка недр ООО «Ариана» по данным геологического изучения (2014-2015 гг.) определены частично. Так как участок недр ООО «Ариана» расположен в пределах ранее разведанного месторождения, при переоценке его запасов могут быть выделены запасы категории В.

Результаты определения запасов подземных вод и их категоризация

Как указывалось выше, Нижне-Кармадонское месторождение минеральных вод детально разведано конец XX в. Запасы минеральных вод утверждены ГКЗ СССР в количестве $2200 \mathrm{~m}^{3} /$ сут по категории А без ограничения срока эксплуатации.

Согласно техническому (геологическому) заданию целью проведения настоящих работ являлась переоценка запасов минеральных вод НижнеКармадонского месторождения на участке ООО «Ариана».

Исходя из перспективной потребности недропользователя максимальный уровень добычи минеральных вод на участке ограничен величиной $360 \mathrm{~m}^{3} /$ сут.

Обоснование запасов минеральных вод участка производилось по скважинам № 27 и 29-р. Подсчет запасов осуществлялся гидравлическим методом, исходя из средней величины дебитов скважин при свободном самоизливе. 
Средний дебит скважин определялся по данным периодических ежемесячных замеров, проведенных в течение одного года, в 2018-2019 гг. (табл. 1).

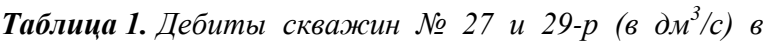
2018-2019 г2.

Table 1. Flow rates of wells no. 27 and $29-r\left(\right.$ in $\left.\mathrm{dm}^{3} / \mathrm{s}\right)$ in $2018-2019$

\begin{tabular}{|c|c|c|}
\hline \multirow{2}{*}{ Дата/Date } & \multicolumn{2}{|c|}{ Скважина №/Well no. } \\
\cline { 2 - 3 } & 27 & $29-\mathrm{p}$ \\
\hline 17.10 .2018 & 0,68 & 1,11 \\
\hline 30.11 .2018 & 0,70 & 1,04 \\
\hline 17.01 .2018 & 0,67 & 1,14 \\
\hline 28.02 .2019 & 0,71 & 1,18 \\
\hline 29.03 .2019 & 0,73 & 1,07 \\
\hline 30.04 .2019 & 0,72 & 1,05 \\
\hline 30.05 .2019 & 0,69 & 1,03 \\
\hline 28.06 .2019 & 0,68 & 1,05 \\
\hline 25.07 .2019 & 0,67 & 1,06 \\
\hline 28.08 .2019 & 0,67 & 1,08 \\
\hline 30.09 .2019 & 0,68 & 1,08 \\
\hline 17.10 .2019 & 0,68 & 1,10 \\
\hline
\end{tabular}

Так как в течение всего этого периода скважины работали в режиме «минеральные воды самоизлива- ются» (закрывались только на время проведения гидрогеологических исследований), регулярные замеры дебита рассматриваются как наблюдения в процессе опытно-эксплуатационных выпусков продолжительностью 12 месяцев.

Из табл. 1 следует, что средний дебит по скважинам составил:

- д для скважины № 27: 0,69 дм³/с; 59,6 м³/сут;

- д для скважины № 29-р: 1,08 дм³/с; 93,3 м³/сут.

Таким образом, определены запасы термальной минеральной питьевой лечебной воды по участку недр ООО «Ариана» Нижне-Кармадонского месторождения, расположенного в Пригородном районе Республики Северная Осетия-Алания в количестве $152 \mathrm{~m}^{3} /$ сут.

Запасы отнесены к категории В (разведанным) и предусматриваются на 25-летний расчетный срок эксплуатации. В табл. 2 приведены сведения о запасах подземных вод участка.

Исходя из особенностей химического состава общие запасы участка распределяются по скважинам следующим образом (табл. 3).

Таблица 2. Сведения о запасах подземных вод участка

Table 2. Information on groundwater reserves of the site

\begin{tabular}{|c|c|c|c|c|c|}
\hline $\begin{array}{l}\text { Тип воды } \\
\text { Water type }\end{array}$ & $\begin{array}{c}\text { Водоносный } \\
\text { горизонт, интервал } \\
\text { каптажа } \\
\text { Aquifer, capturing in- } \\
\text { terval }\end{array}$ & $\begin{array}{c}\text { Минерализация, } \\
\text { г/дм }{ }^{3} \\
\text { Mineralization, } \\
\text { g/dm }{ }^{3}\end{array}$ & $\begin{array}{c}\text { Биологически актив- } \\
\text { ные компоненты, со- } \\
\text { держание, мг/дм }^{3} \\
\text { Biologically active } \\
\text { components, content, } \\
\text { mg/dm }{ }^{3} \\
\end{array}$ & $\begin{array}{c}\text { Запасы } \mathrm{m}^{3} / \text { сут } \\
\text { по категории } \\
\text { «B» } \\
\text { Stocks } \mathrm{m}^{3} / \text { day } \\
\text { for category } \\
\text { «B» } \\
\end{array}$ & $\begin{array}{c}\text { № скважин, } \\
\text { обосновывающих } \\
\text { запасы } \\
\text { No. of wells sub- } \\
\text { stantiating reserves }\end{array}$ \\
\hline $\begin{array}{c}\text { Хлоридная (гидрокарбонатно- } \\
\text { хлоридная) натриевая, борная, } \\
\text { термальная, минеральная } \\
\text { Chloride (hydrocarbonate- } \\
\text { chloride) sodium, boric, thermal } \\
\text { mineral } \\
\end{array}$ & \begin{tabular}{|c|} 
Водоносный комплекс \\
нижнеюрских отло- \\
жений $J_{1} ; 330-817$ м \\
Water-bearing complex \\
of Lower Jurassic de- \\
posits $J_{1} ; 330-817 \mathrm{~m}$ \\
\end{tabular} & $3,2 \ldots 5,7$ & $\begin{array}{c}\text { Ортоборная кислота } \\
\left(\mathrm{H}_{3} \mathrm{BO}_{3}\right), 146-277 \\
\text { Orthoboricacid }\left(\mathrm{H}_{3} \mathrm{BO}_{3}\right), \\
146-277\end{array}$ & 152,0 & $27 ; 29-p$ \\
\hline
\end{tabular}

Таблица 3. Распределение минеральных вод участка по гидрохимическим типам

Table 3. Distribution of mineral waters of the site by hydrochemical types

\begin{tabular}{|c|c|c|c|}
\hline $\begin{array}{c}\text { № } \\
\text { сква } \\
\text { жин } \\
\text { Well } \\
\text { no. }\end{array}$ & $\begin{array}{c}\text { Минерализа- } \\
\text { ция воды, } \\
\text { г/дм } \\
\text { Water minera- } \\
\text { lization, } \mathrm{g} / \mathrm{dm}^{3}\end{array}$ & $\begin{array}{c}\text { Гидрохимический тип вод } \\
\text { по ГОСТ Р 54316-2011 } \\
\text { Hydrochemical type of wa- } \\
\text { ter according to SS R } \\
54316-2011\end{array}$ & $\begin{array}{c}\text { Запасы, } \\
\mathrm{m}^{3} / \text { сут } \\
\text { Re- } \\
\text { serves, } \\
\mathrm{m}^{3} / \mathrm{day}\end{array}$ \\
\hline $29-p$ & $3,3 \ldots 3,6$ & Кармадонский/Karmadon & 59 \\
\hline 27 & $5,4 \ldots 5,7$ & $\begin{array}{c}\text { Кармадонский, } \\
\text { Урс-Донский } \\
\text { Karmadon, Urs-Donskiн }\end{array}$ & 93 \\
\hline
\end{tabular}

Полученная величина суммарного эксплуатационного дебита скважин не в полной мере отражает запасы минеральных вод участка. Нижне-Кармадонское месторождение было разведано в пределах узкой полосы вдоль р. Геналдон на протяжении 1250 м. Протяженность участка недр ООО «Ариана» (обусловленная расстоянием между скважинами № 27 и 29-р) составляет 210 м. Следовательно, охватывая около $17 \%$ площади Нижне-Кармадонского месторождения, оцениваемый участок недр изначально обладает значительной частью разведанных запасов минеральных вод.
Анализ информации по скважинам № 27 и 29-р показывает, что по результатам ранних опытноэксплуатационных выпусков средние дебиты скважин составляли:

- $\quad$ скв. № $27-12,84$ дм $^{3} / \mathrm{c}$;

- скв. № 29-p - 5,75 дм³ $/$ c.

Следовательно, суммарная среднесуточная производительность скважин за исследованный период составляла $1605 \mathrm{~m}^{3} /$ сут (т. е. более чем в 10 раз выше предыдущей).

Таким образом, резкое уменьшение дебитов скважин не связано с ресурсным потенциалом месторождения, а является следствием повреждения скважин селевой массой во время катастрофического схода ледника Колка 20 сентября 2002 г. В перспективе допускается возможность получения дополнительных запасов минеральных вод на участке за счет бурения новой скважины (ремонт существующих скв. № 27 и 29-р с целью увеличения их дебитов не представляется возможным из-за недоступности скважин для буровой техники).

Исходя из величины постоянной разгрузки минеральных вод на площади Нижне-Кармадонского месторождения в количестве 18-200 м³/сут, можно сде- 
лать вывод, что переоцененные запасы минеральных вод участка недр ООО «Ариана» вполне обеспечены источниками формирования.

\section{Предложения по организации и ведению мониторинга состояния недр}

С целью получения своевременной достоверной информации, необходимой для принятия оперативных решений по обеспечению рационального использования минеральных вод участка, контроля за их состоя- нием под воздействием техногенных и природных факторов, предусматривается объектный мониторинг подземных вод [16-20] по прилагаемой схеме (табл. 4).

Фиксация данных мониторинга минеральных вод ведётся в специальном журнале режимных наблюдений, где также должны быть отражены результаты работ по ремонту скважины, отбора проб воды на химические и бактериологические анализы. Рекомендуемая форма журнала наблюдений прилагается в табл. 5.

Таблица 4. Схема объектного мониторинга минеральных подземных вод на участке

Table 4. Scheme of object monitoring of mineral groundwater at the site

\begin{tabular}{|c|c|c|c|c|}
\hline $\begin{array}{c}\text { Объект наблюдения } \\
\text { Observation object }\end{array}$ & $\begin{array}{c}\text { Пункты наблюдения } \\
\text { Observation points }\end{array}$ & $\begin{array}{c}\text { Наблюдаемые показатели } \\
\text { Observed indicators }\end{array}$ & \begin{tabular}{|c|} 
Способ измерения \\
Measurement method \\
\end{tabular} & $\begin{array}{c}\text { Периодичность } \\
\text { Periodicity }\end{array}$ \\
\hline \multirow[b]{4}{*}{$\begin{array}{l}\text { Эксплуатируемый во- } \\
\text { доносный комплек с } J_{1} \\
\text { Exploited aquifer } J_{1}\end{array}$} & \multirow[b]{4}{*}{$\begin{array}{c}\text { Скважины № } 27 \text { и 29- } \\
\text { p } \\
\text { Wells no. } 27 \text { and 29-r }\end{array}$} & $\begin{array}{c}\text { Дебит } \\
\text { Flow rate }\end{array}$ & $\begin{array}{l}\text { Объемный } \\
\text { Volume }\end{array}$ & \multirow{3}{*}{$\begin{array}{l}1 \text { раз в месяц } \\
\text { once a month }\end{array}$} \\
\hline & & $\begin{array}{l}\text { Уровень воды } \\
\text { Water level }\end{array}$ & $\begin{array}{c}\text { По манометру } \\
\text { By pressure gauge }\end{array}$ & \\
\hline & & $\begin{array}{l}\text { Температура воды } \\
\text { Water temperature }\end{array}$ & $\begin{array}{l}\text { Tермометром } \\
\text { Thermometer }\end{array}$ & \\
\hline & & $\begin{array}{l}\text { Контроль качества отбираемой } \\
\text { воды } \\
\text { Quality control of the taken water }\end{array}$ & $\begin{array}{c}\text { По программе произ- } \\
\text { водственного кон- } \\
\text { троля качества } \\
\text { According production } \\
\text { quality control pro- } \\
\text { gram }\end{array}$ & $\begin{array}{c}3 \text { раза в год на типовой (сокра- } \\
\text { щенный) хим. анализ воды; } \\
1 \text { раз в год на полный хим. ана- } \\
\text { лиз воды; } \\
4 \text { раза в год на баканализ воды } \\
3 \text { times a year for a typical (re- } \\
\text { duced) chemical analysis of water; } \\
\text { once a year for a complete chem- } \\
\text { ical analysis of water; } \\
4 \text { times a year for water analysis }\end{array}$ \\
\hline $\begin{array}{c}\text { Техническое состояние } \\
\text { Technical condition }\end{array}$ & $\begin{array}{l}\text { Скважины № } 27 \text { и 29-р } \\
\text { Wells no. } 27 \text { and 29-r }\end{array}$ & $\begin{array}{l}\text { Состояние ствола скважины, усть- } \\
\text { евой обвязки, павильона и т. д. } \\
\text { The condition of the wellbore, } \\
\text { wellhead connection, pavilion, etc. }\end{array}$ & \multirow[b]{2}{*}{$\begin{array}{c}\text { Визуальный осмотр } \\
\text { Visual }\end{array}$} & $\begin{array}{l}1 \text { раз в год } \\
\text { once a year }\end{array}$ \\
\hline $\begin{array}{l}\text { Зона строго режима } \\
\text { High security zone }\end{array}$ & $\begin{array}{l}\text { Участок недр } \\
\text { Subsoil plot }\end{array}$ & $\begin{array}{c}\text { Потенциальные источники за- } \\
\text { грязнения; установленный ре- } \\
\text { гламент хозяйственной деятель- } \\
\text { ности в зоне строгого режима } \\
\text { Potential sources of pollution; es- } \\
\text { tablished regulations for economic } \\
\text { activity in a strict regime zone }\end{array}$ & & $\begin{array}{l}1 \text { раз в год } \\
\text { once a year }\end{array}$ \\
\hline
\end{tabular}

Таблица 5. Форма журнала для проведения режимных наблюдений на участке

Table 5. Form of the journal for conducting regime observations at the site

\begin{tabular}{|c|c|c|c|c|c|c|c|c|}
\hline \multirow[b]{2}{*}{$\begin{array}{c}\text { Дата замера } \\
\text { Measurement } \\
\text { date }\end{array}$} & \multirow[b]{2}{*}{$\begin{array}{c}\text { Время замера } \\
\text { Measurement } \\
\text { time }\end{array}$} & \multicolumn{2}{|c|}{\begin{tabular}{|l|} 
Температура, ${ }^{\circ} \mathrm{C}$ \\
Temperature, ${ }^{\circ} \mathrm{C}$
\end{tabular}} & \multicolumn{3}{|c|}{$\begin{array}{c}\text { Дебит скважины } \\
\text { Well flow rate }\end{array}$} & \multirow{2}{*}{$\begin{array}{c}\text { Уровень во- } \\
\text { ды по мано- } \\
\text { метру, м } \\
\text { Water level } \\
\text { according to } \\
\text { manometer, m } \\
\end{array}$} & \multirow{2}{*}{$\begin{array}{c}\text { № пробы, вид анализа, } \\
\text { ремонтно- } \\
\text { профилактические работы } \\
\text { Sample number, type of } \\
\text { analysis, repair and mainte- } \\
\text { nance work }\end{array}$} \\
\hline & & $\begin{array}{l}\text { воды } \\
\text { water }\end{array}$ & $\begin{array}{l}\text { воздуха } \\
\text { air }\end{array}$ & $\begin{array}{c}\text { объём измери- } \\
\text { тельного сосуда } \\
\text { measuring vessel } \\
\text { volume }\end{array}$ & $\begin{array}{l}\text { время напол- } \\
\text { нения, c } \\
\text { filling time, s }\end{array}$ & $\begin{array}{c}\text { дебит, } \\
\text { дм }^{3} / \mathrm{c} \\
\text { flow rate, } \\
\mathrm{dm}^{3} / \mathrm{s}\end{array}$ & & \\
\hline 1 & 2 & 3 & 4 & 5 & 6 & 7 & 8 & 10 \\
\hline
\end{tabular}

\section{Заключение}

За период исследований проведены работы по определению количества минеральных вод участка недр в южной части Нижне-Кармадонского месторождения.

В настоящее время на участке находятся две действующие скважины: № 27 и 29-р.

В комплекс гидрогеологических исследований вошли: изучение экспериментальных материалов; изучение режима подземных вод; отбор проб; лабораторные исследования.

В процессе работ охарактеризовано современное качество подземных вод целевого водоносного комплекса, оценены условия естественной защищенности подземных вод.
В структурно-тектоническом отношении оцениваемый участок недр приурочен к зоне Северного склона (структура II порядка), входящей в состав антиклинория Большого Кавказа (структура I порядка). Непосредственно геологическое строение участка обуславливает Геналдонская антиклиналь (структура III порядка), сложенная нижнеюрскими отложениями, нарушенная Кауридонским, Нижне-Кармадонским и Тагаурским разломами субширотного простирания с крутым падением на юг. В пределах антиклинали породы развиты субмеридионально-поперечные трещины разрыва, являющиеся основным путями циркуляции минеральных вод.

В гидрогеологическом отношении участок приурочен к восточному краю Центрально-Кавказской 
гидрогеологической складчатой области с бассейнами трещинно-пластовых и трещинно-жильных вод. Циркуляция минеральных вод и их разгрузка происходят по разломам и трещинам субмеридианального направления.

Целевым гидростратиграфическим таксоном является водоносный комплекс трещинно-жильных вод нижнеюрских отложений. Питание массива осуществляется за счет атмосферных осадков на ледниках и снежниках Казбекско-Джимарайского массива. Разгрузка происходит в аллювий или в р. Геналдон.

В соответствии с «Классификацией запасов и прогнозных ресурсов питьевых, технических и минеральных подземных вод», по сложности геологического строения и гидрогеологических условий оцениваемый участок недр можно отнести ко второй группе сложности.

Гидрорежимные наблюдения на участке проведены в 2014-2015 гг. Получены следующие данные:

- в скважине № 27: избыточный напор - до +285 м;

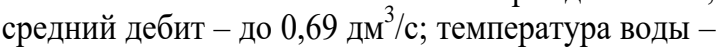
до $50{ }^{\circ} \mathrm{C}$;

- в скважине № 29-р: избыточный напор - до +400 м (расчетное значение); дебит - 1,08 дм³/с; температура - до $45^{\circ} \mathrm{C}$.

\section{СПИСОК ЛИТЕРАТУРЫ}

1. Assessment of exploitation reserves of Nabeghlavi mineral wate deposit / A. Jgamadzea, J. Gabechavaa, V. Gvakhariaa, D. Sozashvilia, B. Lebanidzea, T. Jebashvilia, A. Maglakelidzea // Annals of Agrarian Science. - 2018. - V. 16. - P. 352-356.

2. Ga plume associated VHMS mineralization in the Eastern Goldfields Superterrane, Yilgarn Craton: Insights from the low temperature and shallow water, Ag-Zn-(Au) Nimbus deposit / S.P. Hollis, D.R. Mole, P. Gillespie, S.J. Barnes, R.A.F. Cas, C. Hildrew, A. Pumphrey, M.D. Goodz, S. Caruso, C.J. Yeats, A. Verbeeten, S.M. Belford, S. Wyche, L.A.J. Martin // Precambrian Research. - 2017. - V. 291. - P. 119-142.

3. Geology and hydrogeochemistry of the thermo-mineral waters of the South Rif Thrust (Northern Morocco) / K. Sabri, R. MarreroDiaz, A. Ntarmouchant, T.B. dos Santos, M.L. Ribeiro, A.R. Solá, H. Smaili, A. Benslimane, M. Chibout, N.M. Pérez, E. Padrón, G.V. Melián, M. Asensio-Ramos, P.M. Carreira, A.P. Jesus // Geothermics. -2019 . - V. 78. - P. $28-49$.

4. Comparative geochemical study between the tap waters and the bottled mineral waters in Calabria (Southern Italy) by compositional data analysis (CoDA) developments / C. Apollaro, A. Buccianti, G. Vespasiano, M. Vardè, I. Fuoco, D. Barca, A. Bloise, D. Miriello, F. Cofone, A. Servidio, R. De Rosa // Applied Geochemistry. - 2019. - V. 107. - P. 19-33.

5. Determining the recharge sources and circulation depth of thermal waters in Xianyang geothermal field in Guanzhong Basin: The controlling role of Weibei Fault / Lu Luo, Z. Pang, J. Liu, Sh. Hu, S. Rao, Y. Li, L. Lu // Geothermics. - 2017. - V. 69. - P. 55-64.

6. Hebblewhite B. Fracturing, caving propagation and influence of mining on groundwater above longwall panels-a review of predictive models // International Journal of Mining Science and Technology. - 2020. - V. 30. - P. 49-54

7. Alakangas L.J., Mathurin F.A., Åström M.E. Diverse fractionation patterns of Rare Earth Elements in deep fracture groundwater in the Baltic Shield - progress from utilisation of Diffusive Gradients in Thin-films (DGT) at the Äspö Hard Rock Laboratory // Geochimica et CosmochimicaActa. - 2020. - V. 269. - P. 15-38.

8. Zhan Sh., Wang T., Jeng F. Fracture characterization using hydrogeological approaches and measures taken for groundwater inrush mitigation in shaft excavation // Tunnelling and Underground Space Technology. - 2018. - V. 82. - P. 554-567.
Главной причиной резкого уменьшения дебита скважин, безусловно, является их повреждение ледово-грязекаменной массой во время катастрофического схода ледника Колка 20 сентября 2002 г.

Обобщенный химический состав воды участка в современный период описывается формулой:

$$
\begin{gathered}
\mathrm{M}_{3,2-5,7} \frac{\mathrm{Cl} 91-93\left(\mathrm{HCO}_{3} 7-9\right)}{(\mathrm{Na}+\mathrm{K}) 88-95} \mathrm{H}_{3} \mathrm{BO}_{3} 146- \\
-277 \mathrm{~T} 42-50^{\circ} \mathrm{C} .
\end{gathered}
$$

Сравнение современных результатов исследований с особенностями химического состава минеральных вод и ранее проведенными исследованиями свидетельствует о стабильности показателей состава и свойств минеральных вод.

Проведен комплексный анализ химического состава минеральных вод Нижне-Кармадонского месторождения, и определены физико-химические и лечебные свойства минеральных вод месторождения.

Исходя из величины постоянной разгрузки минеральных вод на площади Нижне-Кармадонского месторождения в количестве $18200 \mathrm{~m}^{3}$ /сут, запасы минеральных вод участка вполне обеспечены источниками формирования.

9. Improving estimates of groundwater velocity in a fractured rock borehole using hydraulic and tracer dilution methods / C.H. Maldaner, P.M. Quinn, J.A. Cherry, B.L. Parker // Journal of Contaminant Hydrology. - 2018. - V. 214. - P. 75-86.

10. Fang H., Zhu J. Simulation of groundwater exchange between an unconfined aquifer and a discrete fracture network with laminar and turbulent flows // Journal of Hydrology. - 2018. - V. 562. P. 468-476.

11. Improving the energy efficiency of technological equipment at mining enterprises / R. Klyuev, I. Bosikov, O. Gavrina, M. Madaeva, A. Sokolov // Advances in Intelligent Systems and Computing. - 2021. - V. 1258. - P. 262-271.

12. Оценка горно-геологических и горнотехнических условий карьера «Северный» с помощью математических моделей / Р.В. Клюев, И.И. Босиков, Е.В. Егорова, О.А. Гаврина // Устойчивое развитие горных территорий. - 2020. - № 3. C. 418-427. DOI: $10.21177 / 1998-4502-2020-12-3-418-427$.

13. Комплексный анализ применения эффективных технологий для повышения устойчивого развития природно-технической системы / Р.В. Клюев, И.И. Босиков, А. В. Майер, О.А. Гаврина // Устойчивое развитие горных территорий. - 2020. - № 2. C. 283-290.

14. Metal deposits combined development experience / V. Golik, V. Komashchenko, V. Morkun, O. Burdzieva // Metallurgical and Mining Industry. - 2015. - V. 7. - № 6. - P. 591-594.

15. Голик В.И., Разоренов Ю.И., Каргинов К.Г. Основа устойчивого развития РСО-Алания - горнодобывающая отрасль // Устойчивое развитие горных территорий. - 2017. - № 2. C. $163-172$.

16. Quantitative decision making for a groundwater monitoring and subsurface contamination early warning network / H. Li, J. Gu, A. Hanif, A. Dhanasekar, K. Carlson // Science of The Total Environment. - 2019. - V. 683. - P. 498-507.

17. Statistical modelling of groundwater contamination monitoring data: a comparison of spatial and spatiotemporal methods / M.I. McLean, L. Evers, A.W. Bowman, M. Bonte, W.R. Jones // Science of The Total Environment. - 2019. - V. 652. - P. 1339-1346.

18. Groundwater quality monitoring network design and optimisation based on measured contaminant concentration and taking solute transit time into account / J. Farlin, T. Gallé, D. Pittois, M. Bayerle, T. Schaul // Journal of Hydrology. - 2019. - V. 573. - P. 516-523.

19. Ayvaz M.T., Elçi A. Identification of the optimum groundwater quality monitoring network using a genetic algorithm based 
optimization approach // Journal of Hydrology. - 2018. -V. 563. P. 1078-1091.

20. Mi Lin, Biswas A., Bennett E.M. Identifying hotspots and representative monitoring area of groundwater changes with time stability analysis // Science of The Total Environment. - 2019. V. 667. - P. 419-426.

\section{Информация об авторах}

Клюев P.B., доктор технических наук, профессор кафедры техники низких температур им. П.Л. Капицы Московского политехнического университета.

Голик В.И., доктор технических наук, профессор кафедры технологии разработки месторождений СевероКавказского горно-металлургического института (государственного технологического университета).

Босиков И.И., кандидат технических наук, доцент кафедры прикладной геологии Северо-Кавказского горнометаллургического института (государственного технологического университета). 
UDC 556.3

\title{
COMPREHENSIVE ASSESSMENT OF HYDROGEOLOGICAL CONDITIONS FOR FORMATION OF MINERAL WATER RESOURCES OF THE NIZHNE-KARMADON DEPOSIT
}

\author{
Roman V. Klyuev1, \\ kluev-roman@ramler.ru \\ Vladimir I. Golik2, \\ v.i.golik@mail.ru \\ Igor I. Bosikov², \\ igor.boss.777@mal.ru \\ ${ }^{1}$ Moscow Polytechnic University, \\ 33, B. Semenovskaya street, Moscow, 107023, Russia. \\ 2 North Caucasian Institute of mining and metallurgy (State Technological University),
44, Nikolaev street, Vladikavkaz, 362021, Russia.
}

\begin{abstract}
Relevance. For many centuries, mankind has been using the sources of healing waters. Mineral water is used for both treatment and prophylaxis. Moreover, its healing properties were manifested with widespread use. Already starting from the XV century BC Indian Vedas gave an idea of the unique properties of mineral waters. Water from mineral and fresh sources was used for hygiene and healing purposes in the Ancient World, in particular in Egypt, Babylon, Assyria. It should be noted that groundwater has always been highly appreciated. The research is caused by the need for a comprehensive study of the Nizhne-Karmadon field to replenish mineral water reserves in the Russian Federation.

The main aim of the research is the comprehensive analysis of chemical composition of mineral waters of the Nizhne-Karmadon deposit and determining the physicochemical and medicinal properties of the mineral waters of the deposit.

Objects: mineral waters of the Genaldon gorge, Nizhne-Karmadon deposit, Kazbek-Dzhimarai massif.

Methods: structural-tectonic method, analogy method, modeling method, geophysical methods - thermal logging of wells, facies analysis method, geomorphological method, subsoil geometrization method. The geothermal conditions of the subsoil area were assessed by measuring the water temperature at the wellheads.

Results. According to the studies carried out, according to GOST R 54316-2011 and «The main criteria for the chemical composition of mineral waters", the waters of the deposit are low and medium mineralized, sodium chloride, boric, high thermal. In terms of physical, chemical and medicinal properties, the mineral waters of the subsoil area of LLC Ariana are recommended for medicinal and drinking purposes in accordance with the attached medical indications. Based on the value of the constant discharge of mineral waters in the area of the deposit in the amount of $18,200 \mathrm{~m}^{3} /$ day, the mineral water reserves of the site are fully provided with sources of formation.
\end{abstract}

\section{Key words:}

Thermal mineral and sodium chloride waters, zones of faults and fractures, field,

complex of fractured-vein waters, thermal logging studies of wells, fault zones, cracks.

\section{REFERENCES}

1. Jgamadzea A., Gabechavaa J., Gvakhariaa V., Sozashvilia D., Lebanidzea B., Jebashvilia T., Maglakelidzea A. Assessment of exploitation reserves of Nabeghlavi mineral water deposit. Annals of Agrarian Science, 2018, vol. 16, pp. 352-356.

2. Hollis S.P., Mole D.R., Gillespie P., Barnes S.J., Cas R.A.F., Hildrew C., Pumphrey A., Goodz M.D., Caruso S., Yeats C.J., Verbeeten A., Belford S.M., Wyche S., Martin L.A.J. 2.7 Ga plume associated VHMS mineralization in the Eastern Goldfields Superterrane, Yilgarn Craton: Insights from the low temperature and shallow water, Ag-Zn-(Au) Nimbus deposit. Precambrian Research, 2017, vol. 291, pp. 119-142.

3. Sabri K., Marrero-Diaz R., Ntarmouchant A., Bento dos Santos T. Ribeiro M.L., Solá A.R., Smaili H., Benslimane A., Chibout M., Pérez N.M., Padrón E., Melián G.V., Asensio-Ramos M., Carreira P.M., Jesus A.P. Geology and hydrogeochemistry of the thermo-mineral waters of the South Rif Thrust (Northern Morocco). Geothermics, 2019, vol. 78, pp. 28-49.

4. Apollaro C., Buccianti A., Vespasiano G., Vardè M., Fuoco I., Barca D., Bloise A., Miriello D., Cofone F., Servidio A., De Rosa R. Comparative geochemical study between the tap waters and the bottled mineral waters in Calabria (Southern Italy) by compositional data analysis (CoDA) developments. Applied Geochemistry, 2019, vol. 107, pp. 19-33.

5. Luo Lu, Pang Z., Liu J., Hu Sh., Rao S., Li Y., Lu L. Determining the recharge sources and circulation depth of thermal waters in
Xianyang geothermal field in Guanzhong Basin: the controlling role of Weibei Fault. Geothermics, 2017, vol. 69, pp. 55-64.

6. Hebblewhite B. Fracturing, caving propagation and influence of mining on groundwater above longwall panels - a review of predictive models. International Journal of Mining Science and Technology, 2020, vol. 30, pp. 49-54.

7. Alakangas L.J., Mathurin F.A., Åström M.E. Diverse fractionation patterns of Rare Earth Elements in deep fracture groundwater in the Baltic Shield - progress from utilisation of Diffusive Gradients in Thin-films (DGT) at the Äspö Hard Rock Laboratory. Geochimica et Cosmochimica Acta, 2020, vol. 269, pp. 15-38.

8. Zhan Sh., Wang T., Jeng F. Fracture characterization using hydrogeological approaches and measures taken for groundwater inrush mitigation in shaft excavation. Tunnelling and Underground Space Technology, 2018, vol. 82, pp. 554-567.

9. Maldaner C.H., Quinn P.M., Cherry J. A., Parker B. L. Improving estimates of groundwater velocity in a fractured rock borehole using hydraulic and tracer dilution methods. Journal of Contaminant Hydrology, 2018, vol. 214, pp. 75-86.

10. Fang H., Zhu J. Simulation of groundwater exchange between an unconfined aquifer and a discrete fracture network with laminar and turbulent flows. Journal of Hydrology, 2018, vol. 562, pp. 468-476.

11. Klyuev R., Bosikov I., Gavrina O., Madaeva M., Sokolov A. Improving the energy efficiency of technological equipment at mining enterprises. Advances in Intelligent Systems and Computing, 2021, vol. 1258, pp. 262-271. 
12. Klyuev R.V., Bosikov I.I., Egorova E.V., Gavrina O.A. Assessment of mining-geological and mining technical conditions of the Severny pit with the use of mathematical models. Sustainable Development of Mountain Territories, 2020, no. 3, pp. 418-427. In Rus. DOI: 10.21177/1998-4502-2020-12-3-418-427.

13. Klyuev R.V., Bosikov I.I., Mayer A.V., Gavrina O.A. Comprehensive analysis of the effective technologies application to increase sustainable development of the natural-technical system. Sustainable Development of Mountain Territories, 2020, no. 2, pp. 283-290. In Rus.

14. Golik V., Komashchenko V., Morkun V., Burdzieva O. Metal deposits combined development experience. Metallurgical and $\mathrm{Mi}$ ning Industry, 2015, vol. 7, no. 6, pp. 591-594.

15. Golik V.I., Razorenov Yu.I., Karginov K.G. The basis of sustainable development of North Ossetia-Alania is the mining industry. Sustainable development of mountain territories, 2017, no. 2 (32), pp. 163-172. InRus.

16. Li H., Gu J., Hanif A., Dhanasekar A., Carlson K. Quantitative decision making for a groundwater monitoring and subsurface contamination early warning network. Science of The Total Environment, 2019, vol. 683, pp. 498-507.
17. McLean M.I., Evers L., Bowman A.W., Bonte M., Jones W.R. Statistical modelling of groundwater contamination monitoring data: a comparison of spatial and spatiotemporal methods. Science of The Total Environment, 2019, vol. 652, pp. 1339-1346.

18. Farlin J., Gallé T., Pittois D., Bayerle M., Schaul T. Groundwater quality monitoring network design and optimisation based on measured contaminant concentration and taking solute transit time into account. Journal of Hydrology, 2019, vol. 573, pp. 516-523.

19. Ayvaz M.T., Elçi A. Identification of the optimum groundwater quality monitoring network using a genetic algorithm based optimization approach. Journal of Hydrology, 2018, vol. 563, pp. 1078-1091.

20. Lin Mi, Biswas A., Bennett E. M. Identifying hotspots and representative monitoring area of groundwater changes with time stability analysis. Science of The Total Environment, 2019, vol. 667, pp. 419-426.

Received: 18 February 2021.

\section{Information about the authors}

Roman V. Klyuev, Dr. Sc., professor, Moscow Polytechnic University.

Vladimir I. Golik, Dr. Sc., professor, North Caucasian Institute of mining and metallurgy (State Technological University).

Igor I. Bosikov, Cand. Sc., assistant professor, North Caucasian Institute of mining and metallurgy (State Technological University). 